\title{
PARENTAL ATTITUDES OF MOTHERS LIVING IN FAMILIES WITH/WITHOUT THE PROBLEM OF AGGRESSION AND VIOLENCE
}

\author{
Małgorzata Przybysz - Zaremba \\ State College of Applied Sciences in Skierniewice, Poland
}

\begin{abstract}
The text is based on its empirical foundations; it concerns the parental attitudes assumed by mothers living in families with the problem of aggression and violence and these that do not experience such a problem. The research was conducted among 710 women bringing up children of different ages. The aim of the study was to answer the following question: What parental attitudes towards children are taken by the mothers living in families where there is a problem of aggression and violence, or lack thereof?. The study used two tools: the scale of family attitudes according to Maria Braun-Gatkowska and the questionnaire of own authorship. The data elements used to develop the obtained results were, among others, $\mathrm{Chi}^{2}$ test and Vxy-Cramer coefficients.
\end{abstract}

Keywords: parental attitudes, aggression, violence, family.

\section{Introduction}

The family is the most important environment for the child's development and upbringing. It is a key place for mental, social, emotional or cultural development. In the family, the child learns to express feelings, thoughts, appropriate reactions and behaviors as well as values of himself, family, other people, basic norms of conduct and preparation for roles that await him in the social environment (Milerski \& Śliwerski, 2000; Przybysz-Zaremba \& Kołodziejski, 2018). It is parents, generally recognized as the first and main teachers, who are mostly responsible for shaping certain attitudes and behaviors that are later introduced and implemented in adult life.

The proper process of socializing and raising a child in a family depends on many different factors, including psychological and social maturity of parents, knowledge of norms related to roles, the ability to disinterested love, acceptance of a role related to their gender and marital role, having the right motivation to perform parental roles, acceptance of persons and roles of the partner and children, mutual adaptation of parents to the conditions occurring in family and also correct relations and attitudes in the family (Grochocińska, 1999). Research (Buist, Decović, Meeus, \& Aken, 2002; Gerrits et al., 2005) regarding intra-family 
relationships shows that other relations and attitudes towards the child are assumed by the mother and the other by the father. Researchers indicate that mothers exhibit more positive sympathy towards children than fathers, which later translates into efficient interpersonal relations. According to S. K. Williams and F. D. Kelly (2005), such a situation is mostly related to women's family roles and tasks. In addition, researchers also indicate (Shearer, Crouter, \& McHale, 2005) that mothers, through more frequent contact with children, have more experience in creating positive relationships with children than fathers.

The correctness of intra-family relationships, especially towards the child, depends on many factors related (inherent) to the family system. One of the important factors is the functioning of families that experience aggression and violence from one of the family members. The problem of aggression and violence in the family occurs all over the world and mainly affects the weaker, i.e. children, youth, women, and the elderly. According to an international UNICEF report, 640 million children in the world do not have a safe roof over their heads (Pilch, 2010). International research indicates that over $80 \%$ of children in the world experience physical aggression and domestic violence (Giacaman, Shannon, Saab, Arya, \& Boyce, 2007). In the United States, about one hundred and four hundred deaths are reported annually due to adult violence. In turn, in Russia, the statistics of domestic violence in respect of children and young people who, for this reason, die are observed to be estimated at the level of $2-2.5$ thousand a year. About 2 million children up to the age of fourteen regularly experience violence on the part of their parents and over 50,000, every year, escape from home for fear of probable aggression and/or violence (IarskaiaSmirnova, Romanov, \& Antonova, 2008). In Poland in 2017, over 92,000 people are reported to have experienced domestic violence, victims of which were mainly women (67,984 people) and minors (13,515 people). Detailed data on violence in Poland is presented in Figure 1.

Research indicates that such pathological-dysfunctional educational environment has a negative impact on the psychophysical functioning of the child and, further, the functioning of the whole family system. Aggression and violence occurring in the family can take various forms (e.g. physical, psychological, economic, sexual) and is most often directed at weaker people (children, women, the elderly). Women/mothers living and raising children in families with the problem of aggression and violence are burdened with excess duties for the family and home; at the same time, many of them experience much unpleasantness and tension, which can often translate into adopted attitudes towards children (Przybysz-Zaremba, 2013). 


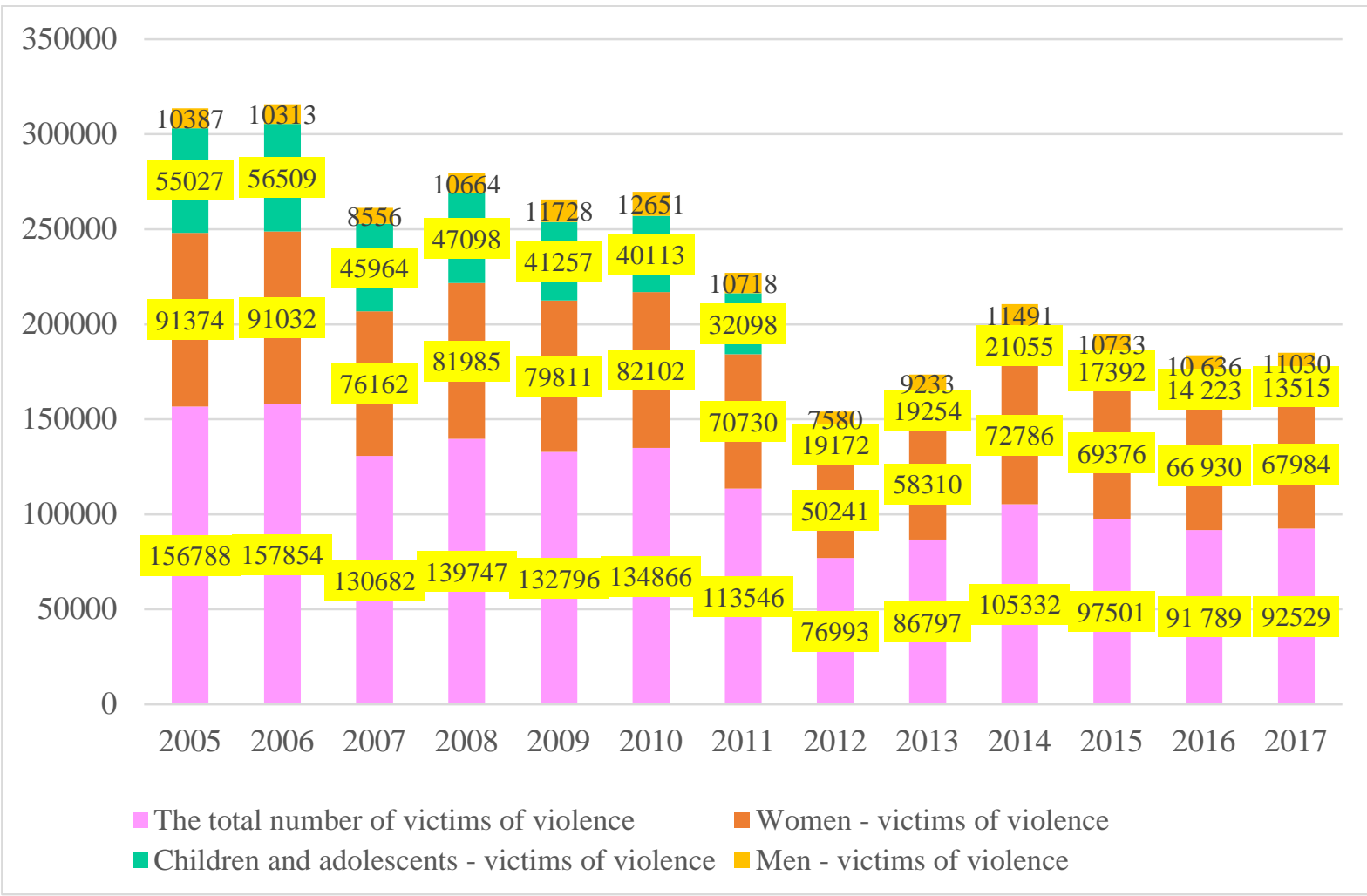

Figure 1 Number of victims of domestic violence in Poland in 2005-2017 (data in thousands). Source: http://statystyka.policja.pl/st/wybrane-statystyki/przemoc-wrodzinie/50863,Przemoc-w-rodzinie.html, Access: January 29 ${ }^{\text {th }}$, 2019r.)

Parental attitudes can be defined as a way of parents' attitude towards a child (Strzelczyk-Muszyńska, 2010), including his/her behavior, experienced problems, and/or education. Thus, they are a holistic form of the attitude of each of the parents (i.e. separately the mother and the father) to the children and to their various educational issues, that has been shaped during the performance of the parents' educational functions (Rembowski, 1972). In the literature, there can be spotted different types and classifications of attitudes adopted by mothers (or both parents) that are opposed to each other, e.g. lenience - severity, tolerance - lack of tolerance, heat - coldness, addiction - separation (Plopa, 2005); acceptance rejection, cooperation - avoidance, reasonable freedom - excessive protection, recognition of rights - excessive demand (Ziemska, 2009); closeness - rejection, help - lack of help and care, management - no standards, complete freedom, requirements - total lack of requirements (Braun-Gałkowska, 1992).

\section{Methodological assumptions of the research}

The aim of the research was to determine parental attitudes assumed by mothers in families who had the problem of aggression and violence, or lack 
thereof. The following research problems have been formulated within the set research goal:

What parental attitudes do mothers take with regard to children, staying in families with the problem of aggression and violence and in families without this problem?

Is there a relationship between the type of parental attitudes adopted by mothers and the problem of aggression and violence in the family or the lack of a problem in the family?

The research was carried out in 2013 on a sample of 710 women/mothers of Polish nationality, bringing up children in families with the problem of aggression and violence and families without this problem. The selection of the sample was random. Women were in the age range: $25-30$ years - 36.34 \%; 31-35 years $26.48 \%$; 36-40 years - 37.18 \%. The surevey used the questionnaire based upon the Family Story Scale developed by Maria Braun-Gałkowska, as well as the questions added by the survey author. The questionnaire concerned the recognition of problems in the family, including the occurrence of the problem of aggression and violence. The Family Attitude Scale refers to four types of attitudes: (a) Closeness - which refers to the emotional distance between family members; (b) Help - which defines the degree of giving help; (c) Targeting which entails the degree of intervention in decisions and the scope of independence; (d) Requirements - which refers to requirements made to family members, as well as the expectations to be possibly revealed by them. On these dimensions one can mark opposing attitudes, recognized as unfavorable from the point of view of one's upbringing. These are the following ones: (a) Rejection, aversion, strangeness - Excessive closeness, emotional viscosity; (b) Lack of help and care - Excessive care, too much protection; (c) No standards, complete freedom - Conducting, excessive management; (d) Total lack of requirements Excessive requirements and demands. Between these attitudes the following ones are recognized: (a) Appropriate closeness; (b) Relevant help; (c) Rational understanding; (d) Appropriate requirements. In the opinion of M. BraunGałkowska, positive attitudes, when they grow too high, turn into negative ones on an excess basis. It is appropriate to consistently contrast two negative extremes (e.g. lack of care - excess of care), at the same time recognizing that there exists a proper attitude between them (such as mature love $n$ the example above). Extreme attitudes are characterized on the one hand by excess, on the other by lack of accuracy, whereas the most appropriate are recognized to be indirect attitudes.

Statistical analysis elements were used to develop the data obtained. The Chi ${ }^{2}$ Test and the Vxy -Cramer Ratio were used. 


\section{Results and discussion}

The research has shown that in 283 (39.90\%) families there was a problem of aggression and violence (in most cases resulting from alcohol abuse), which was most often manifested by husbands/partners of the responding women, while in 427 (60.14 \%) families there no such problem was found.

Analyzing the structure of the women's family, as many as $63.66 \%$ of the respondents bring up their children in full families, $23.80 \%$ in reconstructed families, and $12.54 \%$ in the cohabitation relationship (no legalization of the relationship). The dominant group of families created by women is the family model two plus one and two plus two. $40.9 \%$ of women have one child, thus creating a family model two plus one and $38.2 \%$ form a family with two children (model two plus two). The smallest percentage ratio (20.9\%) concerned women with large families (ie five or more).

Studies have shown that the problem of aggression and violence in the family does not always exert a significant impact on mothers adopting unfavorable parental attitudes from the point of view of parenting. While undergoing a detailed analysis of the attitude of help, one can observe the highest (39.2\%) excess of this attitude recorded among mothers bringing up children in families with the problem of aggression and violence, while in families without this problem the attitude of moderation of help prevails (44.7\%). Excessive attitude of help may be related to the situation and functioning of the family (with the problem of aggression and violence), as well as with age and development of children (they are so small that they require care, assistance and support of one of the parents). Precise data regarding the assumption of the attitude of support by the researched mothers is presented in Figure 2 below.

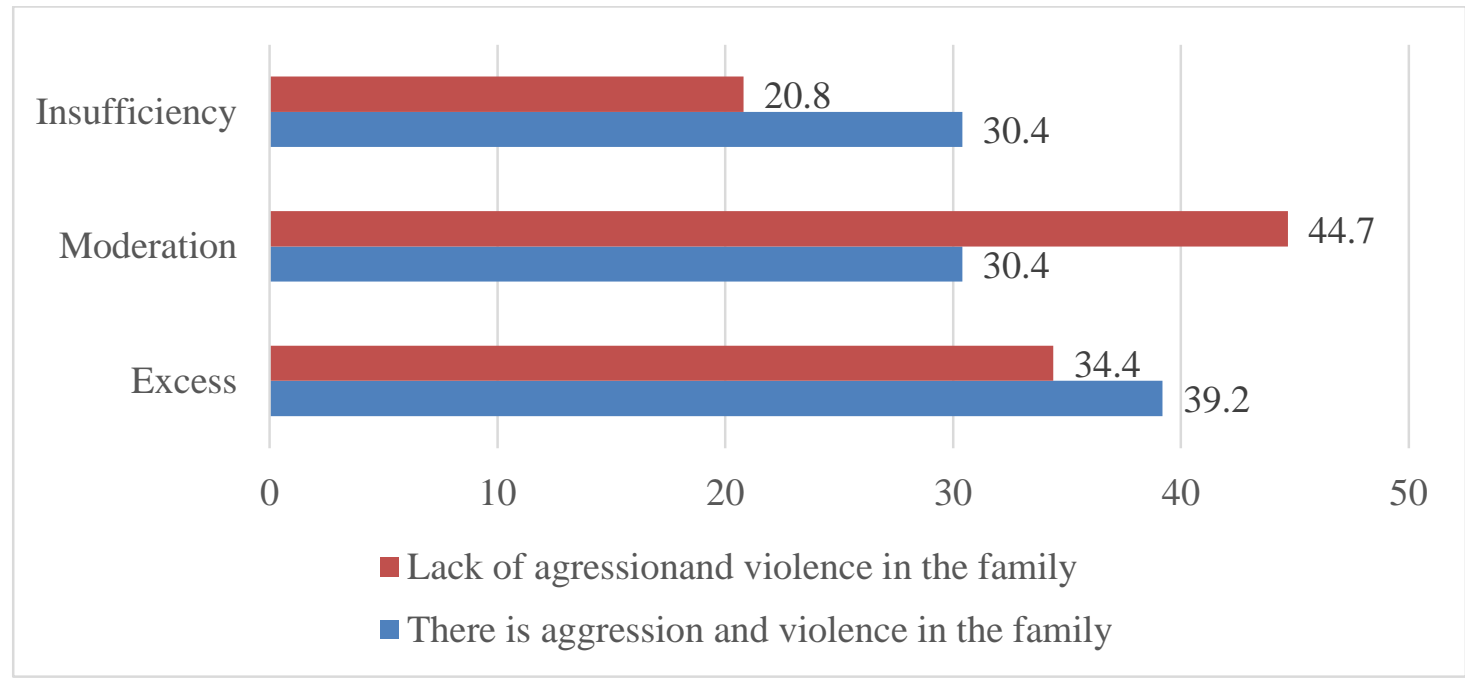

Figure 2 Attitude of help accepted by mothers raising children in families with the problem of aggression and violence and with no such problem. Source: own study based on research 
The above detailed statistical analysis was followed by the analysis of another parental attitude - the one of control, whose highest index (in the area of moderation) (39.8\%) was noted in the families without the problem of aggression and violence, but also in these where the problem of aggression and violence occurred. Precise data regarding the appearance of the attitude of control is presented in Figure 3.

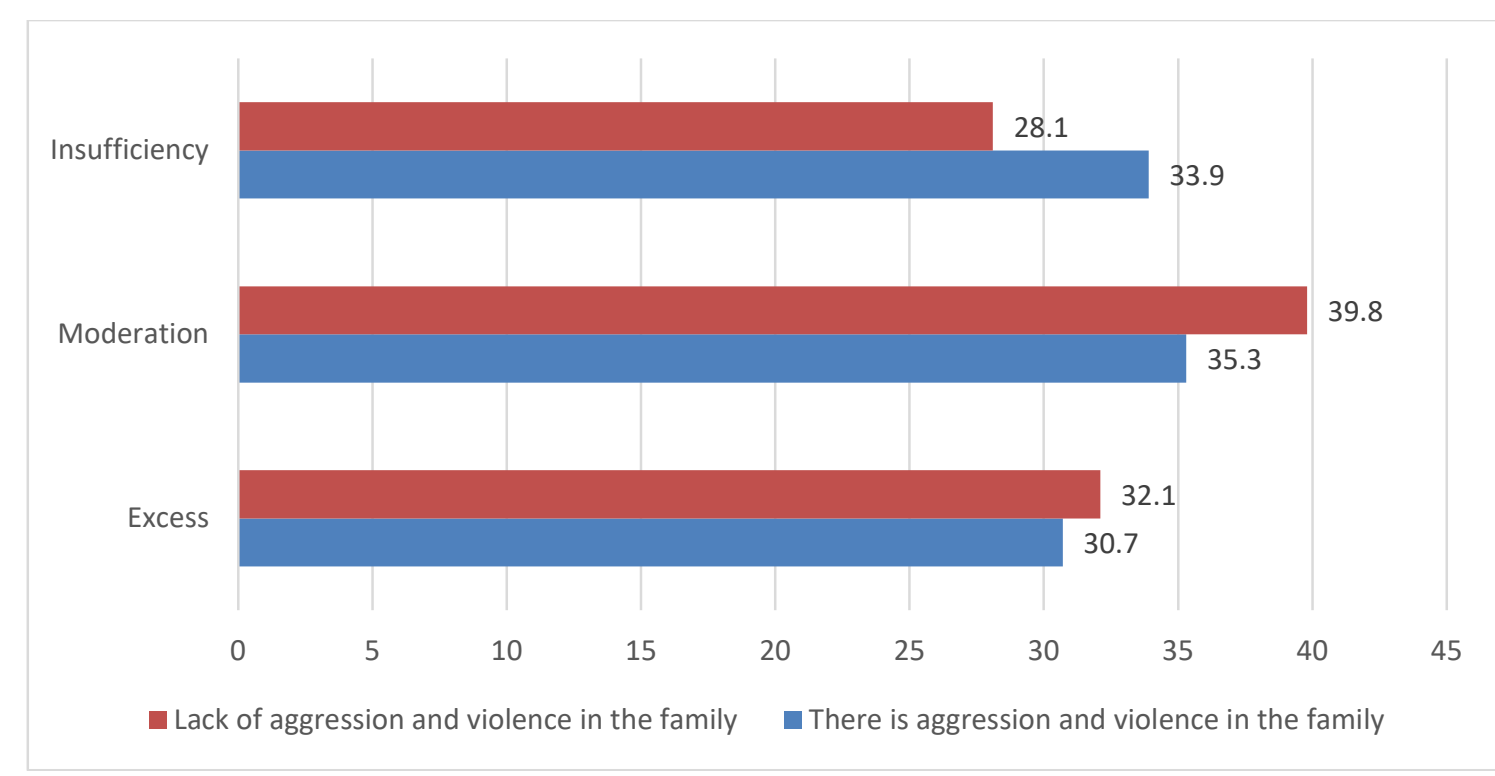

Figure 3 The attitude of control adopted by mothers raising children in families with the problem of aggression and violence and with no such problem. Source: own study based on research

One more parental attitude investigated by us is the attitude of the requirement, which, according to our research, shows a differentiation in relation to the problem of aggression and violence in the family, or lack of it. The data included in Chart 3 shows that in families with the problem of aggression and violence, the excess of the requirement prevails (44.9\%). The lowest indicator refers to the moderation of the requirement (25.1\%). On the basis of these data, it can be concluded that mothers who are overwhelmed by excessive household/family responsibilities, as well as these related to their professional work are not able to cope with all of them, and therefore require their children to help them, especially when it comes to helping them in different household duties (Turiel, 2010). In addition, children burdened with excess of household duties and experiencing stressful situations in the family do not function psychophysically in a proper way, but often display many negative behaviors. This is confirmed, among others by the researchers: Izaguirre \& Calvete (2017), McCann, Lubman, \& Boardman (2017), Qutaiba \& Nazeh (2018), Przybysz-Zaremba (2017, 2014), Smith \& Moore (2013). Analyzing the data on the attitude of 
mothers' requirements towards their children raised in the families with and without the problem of aggression and violence, the data we found is similar; the details are presented in Figure 4.

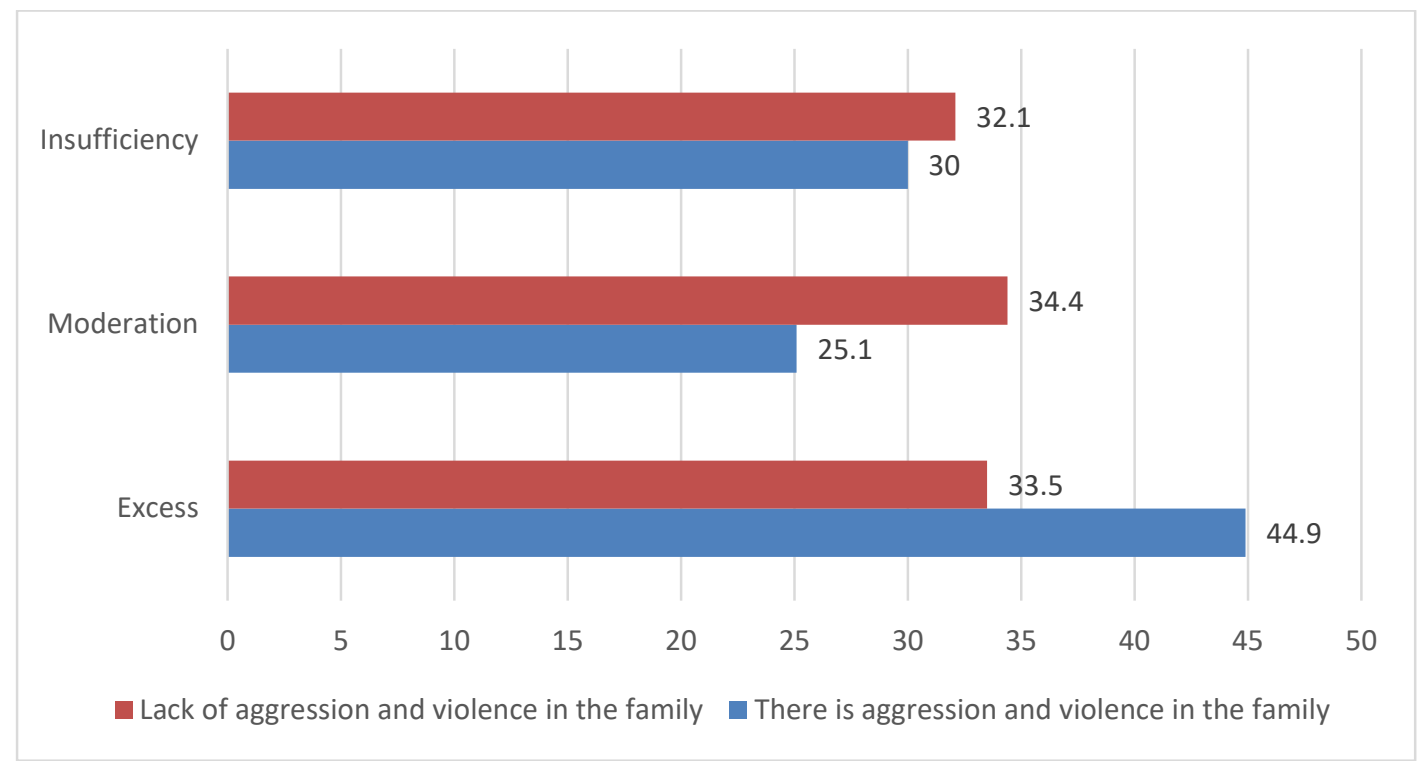

Figure 4 The attitude of the requirement adopted by the mothers raising children in families with the problem of aggression and violence and with no such problem (Source: own study based on research)

One of the attitudes important in the process of children upbringing is the attitude of intimacy. The analysis of the research showed that the data regarding this attitude are very similar in families with the problem of aggression and violence, as well as without this problem. In both groups of families, moderation prevails in terms of the attitude of intimacy (36.7 \% - the problem of aggression and violence occurs, $36.8 \%$ - no such problem is noted). Moderation in terms of the attitude of intimacy adopted by mothers may result from the general situation a family has found itself, lack of help and support, or not the best psychophysical functioning of the mother (Khalifa \& Nasser, 2015). The data regarding excess and underflow of the attitude of intimacy are similar - see Figure 5.

Detailed statistical analysis showed a significant relationship only between the attitude of requirement adopted by the mothers ( $\mathrm{Chi}^{2} \mathrm{emp} .10,87>\mathrm{Chi}^{2}{ }_{\text {tab. }}$,94; $\mathrm{df}=2 ; \quad \alpha=0,05$, V-Cramer coefficient 0.124 ) and the attitude of help (Chi ${ }^{2}$ emp.16,34>Chi ${ }^{2}$ tab.5,94; $\mathrm{df}=2 ; \alpha=0,05 \mathrm{~V}$-Cramer coefficient 0.152) and the problem of aggression and violence occurring in the family. Lack of dependence was found with the attitude of proximity and control. 


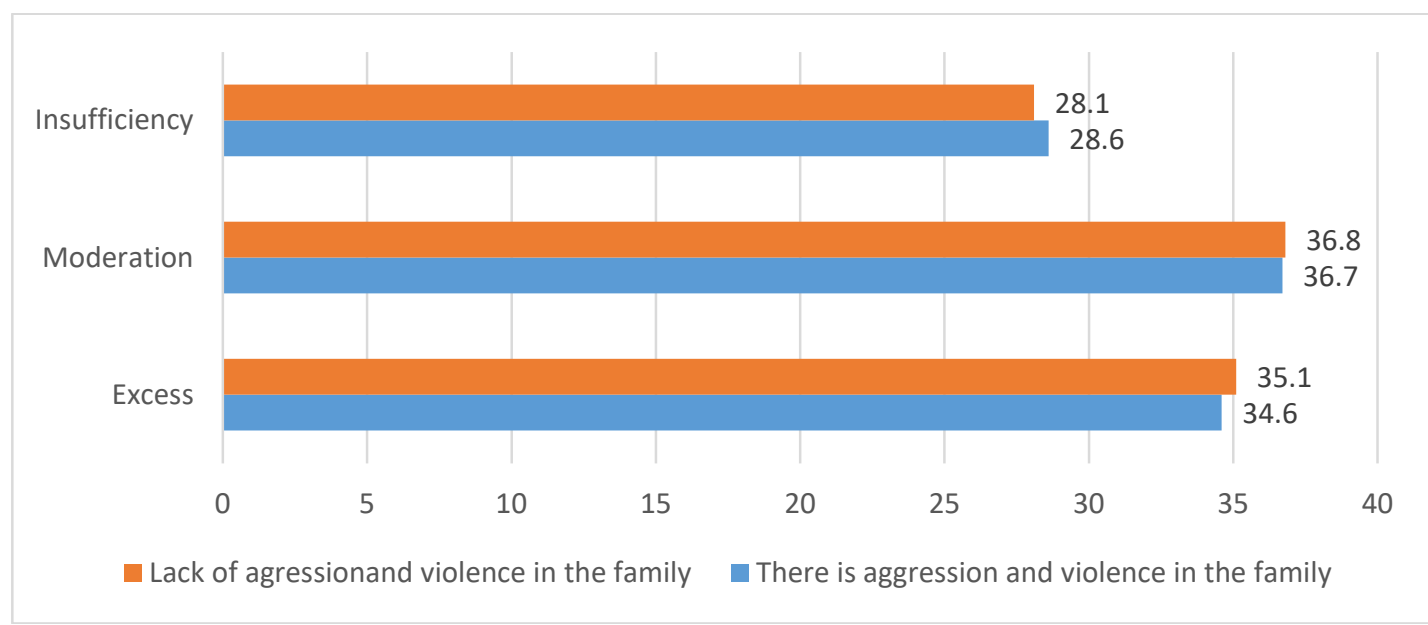

Figure 5 Attitude of intimacy taken by mothers raising children in families with the problem of aggression and violence and with no such problem. Source: own study based on research

Table 1 List of results of statistical analysis

\begin{tabular}{|l|c|c|c|c|c|c|}
\hline \multicolumn{1}{|c|}{$\begin{array}{c}\text { Features under } \\
\text { research }\end{array}$} & $\begin{array}{c}\text { Calculated } \\
\text { Chi2 }\end{array}$ & $\begin{array}{c}\text { Level of } \\
\text { significance }\end{array}$ & $\begin{array}{c}\text { Degrees } \\
\text { of } \\
\text { freedom }\end{array}$ & $\begin{array}{c}\text { Tabulary } \\
\text { Chi2 }\end{array}$ & $\begin{array}{c}\text { Hypothesis } \\
\text { assumption }\end{array}$ & $\begin{array}{c}\text { V-Cramer } \\
\text { coefficient }\end{array}$ \\
\hline $\begin{array}{l}\text { Attitude of } \\
\text { requirement }\end{array}$ & 10,87 & 0,05 & 2 & 5,94 & alternative & 0,124 \\
\hline Attitude of intimacy & 0,03 & 0,05 & 2 & 5,94 & null & 0,006 \\
\hline Attitude of help & 16,34 & 0,05 & 2 & 5,94 & alternaitive & 0,152 \\
\hline Attitude of control & 2,89 & 0,05 & 2 & 5,94 & null & 0,062 \\
\hline
\end{tabular}

Source: own study based on research.

\section{Summary and Conclusions}

The family as the basic institution of socialization and education has an unprecedented impact on the child's development, life and social functioning. In it, the child shapes his/her personality, but in order for it to be formed in a proper way, it requires the creation of positive conditions for it. It is in this light that adopted parental attitudes are to be recognized as one of the important factors influencing the child's development. The following conclusions were made on the basis of the conducted research:

- irrespective of the problem of aggression and domestic violence, women / mothers adopt the following attitudes towards children: help, guidance, requirements, proximity;

- $\quad$ the attitude to excess is prevalent among mothers bringing up children in families with the problem of aggression and violence, whereas in 
families without this problem moderation prevails in terms of this attitude;

- $\quad$ moderation in the attitude of leadership dominates both in families with the problem of aggression and violence, as well as without this problem;

- the attitude of the excess is prevalent among mothers raising children in families with the problem of aggression and violence, while in families without this problem, the highest indicator concerns the moderation of this attitude;

- the attitude of closeness dominates in terms of moderation in both groups of families.

- statistical analysis showed a significant correlation between the problem of aggression and domestic violence and the attitudes of excess and help in most cases lent by the mothers. Such dependencies were not found in the attitude of targeting and proximity.

The parental attitudes adopted by mothers have a significant impact on the psychosocial functioning of the child, and thus on his/her development. Research indicates that externalizing behaviors manifested by children are strictly correlated with the attitudes parents take towards them. Lack of acceptance, support, help and choosing appropriate motivational strategies cause that children model behaviors experienced at home, transferring them often to a peer group. The negative impact of the mother towards the child is shaped by the "distorted picture" of the family, in which basic values such as love, support or trust do not exist (Przybysz-Zaremba \& Kołodziejski, 2016).

\section{References}

Buist, K.L., Decović, M., Meeus, W., \& Aken, van M.A.G. (2002). Developmental patterns in adolescent attachment to mother, father, and sibling. Journal of Youth and Adolescence, 31, 167-176.

Braun-Gałkowska, M. (1992). Metody badania systemu rodzinnego, [Ang: Methods for testing the family system] Lublin: KUL.

Giacaman, R., Shannon, H.S., Saab, H., Arya, N., \& Boyce, W. (2007). Individual and collective exposure to political violence: Palestinian adolescents coping with conflict. The European Journal of Public Health, 17, 4, 361-368.

Grochocińska, R. (1999). Przemoc wobec dziecka w wieku przedszkolnym i wczesnoszkolnym. [Ang: Violence against a pre-school and early school child.] Gdańsk: Wydawnictwo Uniwersytetu Gdańskiego.

Iarskaia-Smirnova, E.R., Romanov, P.V., \& Antonova, E.P. (2008). Domestic Violence Against Children. Strategies of Explanation and Counteraction. Russian Education and Society, 50, 11, 20-35.

Izaguirre, A., \& Calvete, E. (2017). Exposure to Family Violence as a Predictor of Dating Violence and Child-to-Parent Aggression in Spanish Adolescents. Youth \& Society, 49, 3, 393-412. 
Przybysz - Zaremba, 2019. Parental Attitudes of Mothers Living in Families with/without the Problem of Aggression and Violence

Khalifa, B., \& Nasser, R. (2015). Parental Styles and Closeness to the Domestic Servant as Perceived by the Children of Qatar. Journal of Developing Areas, 49, 6, 497-504.

McCann, T.V., Lubman, D.I., \& Boardman, G.F.M. (2017). Affected family members' experience of, and coping with, aggression and violence within the context of problematic substance use: a qualitative study. BMC Psychiatry, 17 (6/2), 1-11.

Milerski, B., \& Śliwerski, B. (eds.) (2000). Pedagogika. Leksykon. [Ang.: Pedagogy. A lexicon] (p. 192). Warszawa: PWN.

Pilch, T. (2010). Miliard dzieci bez szczęścia, [Eng: One billion children without happiness]. Chowanna, 1(34), 41-50.

Plopa, M. (2005). Psychologia rodziny: teoria i badania, [Ang: Family psychology: theory and research] Kraków: Oficyna Wydawnicza „Impuls”.

Przybysz-Zaremba, M. (2017). Uwarunkowania rodzinne zachowań ryzykownych dzieci i młodzieży - analiza wybranych czynników, [Ang: Family determinants of risky behavior of children and adolescents - analysis of selected factors]. Forum Pedagogiczne, 1, 137148. DOI: http://dx.doi.org/10.21697/fp.2017.1.10

Przybysz-Zaremba, M. (2014). (Nie)spokojny dom - rekonstrukcje dzieciństwa Dorosłych Dzieci Alkoholików, [Ang.: (Un) quiet home - childhood reconstructions of Adult Children of Alcoholics]. In W. Danilewicz \& W Theiss (Eds.), Pedagogika społeczna wobec zagrożeń człowieka i idei sprawiedliwości społecznej (pp. 567-582). Warszawa: Wydawnictwo Akademickie Żak.

Przybysz-Zaremba, M., \& Kołodziejski, M. (2016). Wszystko zaczyna się w rodzinie...Kilka uwag na temat wychowania, [Ang.: It all starts in the family ... A few comments about upbringing]. Studia nad Rodzina, 3(40), 7-22.

Przybysz-Zaremba, M., \& Kołodziejski, M. (2018). Socialising-emancipatory function of family. Selected aspects in 'the information jungle'. In M. Przybysz-Zaremba, W. Ziarek (Eds.), FAMILY. Tasks, help, support. Selected aspects (pp. 17-30). Vilnius: Mykolas Romeris University.

Przybysz-Zaremba, M. (2013). Parental attitudes of mothers in pathological families Attitude analysis in the context of aggression and/or violence as well as alcohol abuse occurring in the family - based on own research, In M. Bargel, E. Janigová, E. Jarosz, M. Júzl (Eds.), Sociální v kontextu životních etap človéka (pp. 516-535). Brno: Institut mezioborowých studií.

Qutaiba, A., \& Nazeh, N. (2018). The relationship between violence in the family and adolescents aggression: The mediator role of self-control, social support, religiosity, and well-being. Children \& Youth Services Review, 91, 447-456.

Rembowski, J. (1972). Więzi uczuciowe $w$ rodzinie, [Ang.: Emotional bonds in the family] Warszawa: PWN.

Shearer, C. L., Crouter, A. C., \& Mchale, S. M. (2005). Parents' perceptions of changes in mother-child and father-child relationships during adolescence. Journal of Adolescent Research, 20(6), 662-684.

Smith, D. E., \& Moore, T. M. (2013). Family Violence and Aggression and Their Associations with Psychosocial Functioning in Jamaican Adolescents. Journal of Family Issues, 34(6), 745-767.

Strzelczyk- Muszyńska, D. (2010). Postawy rodzicielskie a kompetencje społeczne. In T. Rostowska, A. Jarmołowska (Eds.), Rozwojowe $i$ wychowawcze aspekty życia rodzinnego (p. 286), [Ang: Developmental and educational aspects of family life.] Warszawa: Wydawnictwo Difin. 
SOCIETY. INTEGRATION. EDUCATION

Proceedings of the International Scientific Conference. Volume III, May $24^{\text {th }}-25^{\text {th }}$, 2019. 360-370

Turiel, E. (2010). Domain Specificity in Social Interactions, Social Thought, and Social Development. Child Development, 81(3), p. 720.

Williams, S. K., \& Kelly, F. D. (2005). Relationships among involvement, attachment, and behavioral problems in adolescence: Examining father's influence. The Journal of Early Adolescence, 25(2), 168-196.

Ziemska, M. (2009). Postawy rodzicielskie, [Ang: Parental attitudes] Warszawa: Wydawnictwo „Wiedza Powszechna”. 